\title{
MDPs: Reflections from the US Perspective
}

Laurel S. Terry

Iterry@psu.edu

Follow this and additional works at: https://ideas.dickinsonlaw.psu.edu/fac-works

\section{Recommended Citation}

Laurel S. Terry, MDPs: Reflections from the US Perspective, 8 Int'l J. Legal Prof. 151 (2001).

This Article is brought to you for free and open access by the Faculty Scholarship at Dickinson Law IDEAS. It has been accepted for inclusion in Faculty Scholarly Works by an authorized administrator of Dickinson Law IDEAS. For more information, please contact lja10@psu.edu. 


\title{
MDPs: reflections from the US perspective
}

\author{
LAUREL S. TERRY
}

The Dickinson School of Law, The Pennsylvania State University, USA

As Elspeth Deards has indicated in her article, MDPs have been on the agenda of numerous bar associations around the world. While her article examines this phenomenon from the English perspective, this article focuses on the responses to MDPs from the United States. The purpose of this article is to provide information that will be useful for comparative reflections about MDPs.

This article begins with a section that focuses on the American Bar Association response to the MDP phenomenon. It continues by noting developments that have occurred in the United States during the past year. Thirdly, it highlights those issues that have been of particular concern in the US. Finally, the article concludes by pointing out some areas in which the US approach to MDPs may differ from the English approach described by Elspeth Deards.

\section{Background information about the US lawyer regulatory system and the American Bar Association}

The United States is a federal system. Under this system, the federal government adopts federal laws and the state governments adopt state laws. For the most part, the regulation of US lawyers is handled by the individual states, rather than the federal government. ${ }^{1}$ Moreover, in most US states the laws and rules regulating lawyers are generally adopted by the judicial branch of government (usually the state Supreme Court), rather than the legislative branch. ${ }^{2}$ The rationale for this is based on the constitutional doctrine of separation of powers. ${ }^{3}$ Thus, in order to determine whether MDPs are permitted in a particular US state, one must look to the regulation in that state. In many US states, the local bar associations offer recommendations to the state supreme court or other regulatory body about the state rules that should govern lawyers. ${ }^{4}$

As this discussion shows, the American Bar Association (ABA) has no actual power to adopt the rules that govern US lawyers. Notwithstanding this lack of actual power, the ABA's suggestions have been very influential. Historically, when state

Address for correspondence: Professor Laurel S. Terry, The Dickinson School of Law, The Pennsylvania State University, 150 South College Street, Carlisle, PA 17013-2899, USA. E-mail: Lterry@psu.edu 
bar associations offer recommendations to the state governing body, the state bar associations have relied heavily upon the work of, and recommendations made by, the American Bar Association (ABA). ${ }^{5}$ For example, in 1969 the ABA approved the Model Code of Professional Responsibility. This Model Code had no binding power itself, but it was adopted verbatim as a binding set of rules in 49 US states (with California the exception). ${ }^{6}$

In 1983, the ABA issued a new set of model rules for lawyers. This new document was called the Model Rules of Professional Conduct. ${ }^{7}$ Although the ABA Model Rules have been adopted in more than 40 US states, the ABA Model Rules have rarely been adopted verbatim. Instead, each state has made significant changes in at least some rules. ${ }^{8}$ Currently, the ABA is engaged in a multi-year project to revise and update the ABA Model Rules of Professional Conduct. The formal name of this project is the Commission on the Evaluation of the Rules of Professional Conduct, but it is commonly referred to as "Ethics 2000" or the "Ethics 2000 Commission". ${ }^{9}$ In August 2001, the ABA began voting on the Ethics 2000 Commission's recommendations. The Ethics 2000 Commission maintains an excellent web page that allows one to follow the work of this Commission. ${ }^{10}$

\section{The status of MDP rules in US states}

As the prior section shows, there is currently significant variation among the US states with respect to their rules regulating lawyers. On issues such as confidentiality and imputation of conflicts of interest, US states have radically different (and sometimes mutually exclusive) provisions. ${ }^{11}$ There is one issue, however, on which there is virtually no state variation - and that is sue is MDPs. With one exception, every US jurisdiction has followed the principles found in the ABA Model Code of Professional Responsibility and the ABA Model Rules of Professional Conduct. ${ }^{12}$ These rules prohibit lawyers from sharing fees with non-lawyers and prohibit lawyers and nonlawyers from serving as partners. As Elspeth Deards noted in her article, the one exception is the District of Columbia. District of Columbia Rule of Professional Conduct 5.4 permits lawyers and non-lawyers to be partners provided that the sole purpose of such partnership is the delivery of legal services. ${ }^{13}$ Because of the requirement that the MDP be devoted solely to the delivery of legal services, even DC Rule 5.4 would not permit the "Big 5"-type of MDPs discussed in Ms Deard's article.

\section{The ABA Commission on Multidisciplinary Practice}

In August 1998, ABA President Phil Anderson appointed a Commission on Multidisciplinary Practice. Among the reasons for the appointment of this Commission was the growing awareness of the "MDP phenomenon", in which an increasing number of lawyers were working in non-traditional settings such as the Big 5 firms, doing work that if done in a law firm setting would be considered the practice of law. ${ }^{14}$ The ABA MDP Commission was directed to:

study and report on the extent to which and the manner in which profes- 
sional service firms operated by accountants and others who are not lawyers are seeking to provide legal services to the public.

As part of its work, it was asked to analyse:

- the experience of clients, foreign and domestic, who have received legal services from professional service firms, and report on international trade developments relevant to the issue;

- existing state and federal legislative frameworks within which professional service firms may be providing legal services, and recommend any modifications or additions to that framework that would be in the public interest;

- the impact of receiving legal services from professional service firms on a client's ability to protect privileged communications and to have the benefit of advice free from conflicts of interest; and

- application of current ethical rules and principles to the provision of legal services by professional service firms, and recommend any modifications or additions that would serve the public interest. ${ }^{15}$

During its tenure, the ABA MDP Commission created a superb website. All of the items described in the subsequent paragraphs are available on this website as links from the Commission's Homepage.

Before it issued its first Report and Recommendations in June 1999, the ABA MDP Commission held three sets of "public hearings" at which interested individuals or group representatives could appear before the Commission and offer their views. These hearings were held in November 1998, February 1999, and March 1999. ${ }^{16}$ Those who "testified" in person before the ABA Commission included consumer representatives; state and local bar representatives; actual or potential MDP clients; Big 5 and accounting organisation representatives; lawyers working for ancillary businesses or in a non-legal capacity; private legal practitioners from very large firms and very small firms; in-house counsel; lawyers and judges who had observed the Big 5's lawyer and non-lawyer work product; representatives of ABA sections, committees, or other entities; other lawyer organisations; malpractice insurance representatives; unauthorised practice of law ("UPL") committee representatives; law school placement officials; organisations and individuals with dual CPA and lawyer qualifications and the organisations that represent them; representatives from the Securities and Exchange Commission ("SEC"); as well as academics in tax, accounting, legal history, and ethics. Witnesses included those who were strongly opposed to lifting the MDP ban and those who were strongly in favour of adopting regulations to permit MDPs.

In June 1999, following these three sets of hearings, the ABA MDP Commission issued a report that recommended that the ABA Model Rules of Professional Conduct be changed in order to permit MDPs between lawyers and non-lawyers. ${ }^{17}$ For MDPs that were not controlled by lawyers, this report recommended the creation of an administrative certification and audit procedure.

At the ABA Annual Meeting in August 1999 in Atlanta, the ABA House of Delegates effectively defeated the ABA MDP Commission report when it voted in favour of a resolution that: 
[T] he American Bar Association make no change, addition or amendment to the Model Rules of Professional Conduct which permits a lawyer to offer legal services through a multidisciplinary practice unless and until additional study demonstrates that such changes will further the public interest without sacrificing or compromising lawyer independence and the legal profession's tradition of loyalty to clients. ${ }^{18}$

Following the defeat of its first Report, the ABA MDP Commission held additional public hearings in August 1999, October 1999 and February 2000. In March 2000, the ABA MDP Commission issued a draft version of its second Report and Recommendations. After receiving comments on the draft, the ABA MDP Commission issued its second Report and Recommendations in May 2000. This second report also recommended that the ABA Model Rule forbidding MDPs be amended, although the second report contained much less detail than the first report. ${ }^{19}$

This second report was rejected by the ABA House of Delegates by a 3-1 margin during the ABA Annual Meeting held in July 2000 in New York City. After a vigorous debate, the ABA House of Delegates affirmed the current ban on MDPs, disbanded the ABA Commission on Multidisciplinary Practice, and recommended that the ABA Standing Committee on Ethics \& Professional Responsibility consider whether changes to the ethics rules were necessary in order to assure that there are safeguards in the ethics rules related to strategic alliances and contractual arrangements between lawyers and non-lawyers. ${ }^{20}$ In adopting this resolution, the ABA House of Delegates defeated a motion to substitute a competing resolution to the effect that the ABA take no further actions to discourage further discussion of MDPs and that MDPs be included within the jurisdiction of the ABA Committee on Research into the Future of the Legal Profession. ${ }^{21}$

Although the ABA defeated both recommendations proposed by the ABA MPD Commission, the ABA continues to serve as an information clearing-house for those interested in issues related to MDPs; the ABA Center for Professional Responsibility has retained on its website the web page created by the ABA Commission on Multidisciplinary Practice. Thus, one can find on this web page all of the testimony (written and oral) submitted by interested parties who appeared before the ABA MDP Commission. One can also find seven charts that organise, according to 40 issues, the written and oral comments of all individuals who testified before the Commission issued its first report. ${ }^{22}$ Therefore, it is possible to select a single issue (e.g. is there client demand for MDPs?) and learn what, if anything, each witness had to say about that issue.

The ABA MDP Commission's website also contains the written comments that were submitted in lieu of in-person testimony. One can also find copies of all of both sets of Reports and Recommendations submitted to the ABA and the written replies the ABA MDP Commission received in response to these reports. In addition, one can read the excellent analyses that were contained in the fanuary 1999 Background Paper on Multidisciplinary Practice: Issues and Developments and the December 1999 Updated Background and Informational Report. One can also find a 
document entitled Hypotheticals and Models, which is referred to below in Section 6 and includes the ABA MDP Commission's vision about the manner in which MDPs might be organised. The website also includes the Commission's February 2000 Postscript to Midyear Meeting, a Bibliography, a list of useful links to state MDP web pages, some selected MDP papers, and links to other ABA MDP sites. (For example, the ABA Section of Law Practice Management also maintains an extensive MDP web page and listserv.) In short, this web page is exceedingly useful for anyone interested in MDPs.

\section{US state developments regarding MDPs}

Before the July 2000 ABA Annual Meeting at which the ABA MDP Commission's second Report and Recommendation were considered, the ABA MDP Commission posted on its website a chart showing, state-by-state, the activities of state bar associations, regulators and MDP committees. ${ }^{23}$ Subsequent to the July 2000 ABA Annual Meeting, the ABA Center for Professional Responsibility, with the assistance of the Oregon State Bar, has periodically posted updated versions of the chart, together with an Update Narrative that explains the chart entries in greater detail. ${ }^{24}$ At the time this article was prepared, the most recent version of this chart was dated 21 November 2001 . According to these charts, thirteen bar associations have pending recommendations to change the state rules to permit some form of MDPs; one state has recommended a change in the definition of the practice of law. On the other hand, 17 state bar associations have rejected, at either the committee level or governing body level, proposals to change the "no-MDP" rule; 1 state has a divided report. Numerous states are still studying the issue. In short, as this information shows, the US currently lacks a consistent and coherent approach to the issue of regulating MDPs. ${ }^{25}$

\section{MDP issues of particular concern in the US}

Elspeth Deards has outlined in her article the arguments offered in support of and against MDPs. While all of the arguments Deards discusses have appeared in the US, some of these arguments have received less emphasis in the US than in England. For example, in my view, the October 1998 Consultation issued by the Law Society of England and Wales devoted much more time to the logistical issues regarding attorney-client privilege and maintenance of a client security fund than did the two ABA reports. ${ }^{26}$ Some points mentioned in Deard's article have been disputed in the US. For example, the Preliminary Report of the State Bar of Texas MDP Task Force questioned the assumption that MDPs would be able to save money for clients and suggested that MDPs might in fact increase costs for clients. ${ }^{27}$

In this author's view, there have been three issues that have raised the most concern in the US about whether MDPs should be permitted at all. The first problem with MDPs that is usually cited is concern about the effect of an MDP on a lawyer's independence. MDP critics charge that lawyers who work for non-lawyers will not be able to determine the best course of action for their clients or act on their judgments. ${ }^{28}$ 
Second, US MDP critics have charged that a lawyer's duty of confidentiality is fundamentally in conflict with an auditor's obligations to the public. ${ }^{29}$ This issue is viewed by many as a "deal breaker" for MDPs. Some MDP proponents have responded to this argument by suggesting that the same MDP should not be permitted to offer simultaneous legal and auditing services to the same client. ${ }^{30}$ Not all commentators accept the validity of this argument, however. At least one commentator has suggested that public interest is well served by having the same firm provide legal and audit services. ${ }^{31}$

Third, many US MDP critics charge that MDPs simply won't work-at least with accountants-because of fundamental differences in the manner in which lawyers define conflicts of interest and accountants define conflicts of interest. ${ }^{32}$

Although the American Bar Association and US commentators "discovered" the MDP issue relatively late in comparison to European bar associations and commentators, they have begun to develop a rich literature about this topic. At least three university law schools have held live symposia and devoted an issue of their law journals to the topic of MDPs. Thus, one can read numerous articles about MDPs by leading commentators in:

- The Phyllis W. Beck Chair in Law Symposium: New Roles, No Rules? Redefining Lawyers' Work; ${ }^{33}$

- The Future of the Profession: A Symposium on Multidisciplinary Practice; ${ }^{34}$ and

- Business Law Symposium: Multidisciplinary Practice. ${ }^{35}$

Other law journals have published single articles about MDPs, such as that by Mary Daly, "Choosing wise men wisely: the risks and rewards of purchasing legal services from lawyers in a multidisciplinary partnership". ${ }^{36}$ Other law schools are currently planning to hold MDP symposia.

In addition to these journal articles, several professors testified before the ABA MDP Commission. Thus, by going to the "hearings" section of the ABA MDP Commission Homepage, one can read the comments of Professor John Dzienkowski (Professor, University of Texas School of Law-5 February 1999); Professor Linda Galler (Professor, Hofstra University School of Law-13 November 1999); Professor Harold Levinson (American Association of Attorney-Certified Public Accountants and Professor, Vanderbilt University School of Law-13 November 1998); Professor Laurel S. Terry (Professor, The Dickinson School of Law of the Pennsylvania State University-12 March 1999); and Professor Bernard Wolfman (Professor, Harvard Law School-12 March 1999).

The range of views offered by these commentators is beyond the scope of this brief article. It is worth noting, however, that a significant body of academic and professional literature about MDPs has appeared and is continuing to evolve in the US.

\section{Some observations about the US and English approaches to MDPs}

In a journal such as this, it is interesting to compare the approaches taken in different countries to similar issues. One of the most striking differences between the ABA 
approach and the approach of the Law Society of England and Wales is- of coursethe difference in result. Whereas the ABA has rejected any rule change to permit MDPs, the Law Society Council has now voted in favour of change. ${ }^{37} \mathrm{~A}$ second interesting difference, which may be related to the first, is the method by which rule changes for the legal professions occur in each country. A third interesting difference is the manner in which each group presented the MDP options. The five models contained in the ABA MDP Commission's document entitled Hypotheticals and Models look significantly different from the models identified in the Law Society's October 1998 Consultation. These differences undoubtedly are due in part, if not entirely, to the different regulatory structure and requirements. Hence, it appears that while each country may have something to learn from the other's experiences in regulation, neither country is in a position to adopt wholesale the solutions developed in the other.

\section{Conclusion}

The MDP phenomenon appears well entrenched and one with which bar associations and regulators will continue to grapple. Because many countries will have to consider similar issues with respect to MDPs, the comparative analyses, such as those found in this journal, should prove useful. ${ }^{38}$

\section{Notes}

[1] Charles W. Wolfram, Modern Legal Ethics (Practitioner's Edition, 1986).

[2] Ibid.

[3] Ibid.

[4] Laurel S. Terry, A survey of legal ethics education in law schools, in: Legal Ethics in Academia (Pennsylvania Academy of Science, 2000), Ch. 5.

[5] Ibid.

[6] Wolfram, op. cit.

[7] American Bar Association, Model Rules of Professional Conduct (1983- 2001), available at http:// www.abanet.org/cpr/mrpc/mrpc_toc.html.

[8] Cornell Legal Information Institute, American Legal Ethics Library, available at http://www.law. cornell.edu/ethics/ (contains state ethics rules).

[9] American Bar Association Center for Professional Responsibility, Ethics 2000 Homepage available at www.abanet.org/cpr/ethics2k.html.

[10] Ibid.

[11] Thomas D. Morgan \& Ronald D. Rotunda, Selected Standards on Professional Responsibility (2001), Appendix A, B and C to the ABA Model Rules of Professional Conduct (these Appendices, which were reprinted with permission of Attorneys' Liability Assurance Society, Inc., are charts that compare the US states' different treatment of the issues of confidentiality, conflicts of interest screening, and the requirement of written fee agreements).

[12] Laurel S. Terry, A primer on MDPs: should the "no" rule become a new rule? (2000) 72 Temple Law Review 869 [hereafter Terry, MDP primer]. (The ABA MDP Commission cited this article in note 54 of its May 2000 Report; it also contains the "Issue Checklist".)

[13] American Bar Association Commission on Multidisciplinary Practice, Background Paper on Multidisciplinary Practice: Issues and Developments, January 1999, available at http://www.abanet.org/cpr/ multicomreport0199.html. 
[14] Terry, MDP primer, op. cit.

[15] American Bar Association, Commission on Multidisciplinary Practice, Mission Statement, available at http://www.abanet.org/cpr/mdp_abt_commission.html.

[16] American Bar Association Commission on Multidisciplinary Practice Homepage available at http: // www.abanet.org/cpr/multicom.html.

[17] This report is available as a link from the ABA MDP Commission Homepage.

[18] Available as a link from the ABA MDP Commission Homepage.

[19] Terry, MDP primer, op. cit.

[20] The full text of this resolution states:

\section{RECOMMENDATION 10F}

RESOLVED, that each jurisdiction is urged to revise its law governing lawyers to implement the following principles and preserve the core values of the legal profession:

1. It is in the public interest to preserve the core values of the legal profession, among which are:

(a) the lawyer's duty of undivided loyalty to the client,

(b) the lawyer's duty competently to exercise independent legal judgment for the benefit of the client;

(c) the lawyer's duty to hold client confidences inviolate;

(d) the lawyer's duty to avoid conflicts of interest with the client; and

(e) the lawyer's duty to help maintain a single profession of law with responsibilities as a representative of clients, an officer of the legal system, and a public citizen having special responsibility for the quality of justice.

(f) The lawyer's duty to promote access to justice.

2. All lawyers are members of one profession subject in each jurisdiction to the law governing lawyers.

3. The law governing lawyers was developed to protect the public interest and to preserve the core values of the legal profession, that are essential to the proper functioning of the American justice system.

4. State bar associations and other entities charged with attorney discipline should reaffirm their commitment to enforcing vigorously their respective law governing lawyers.

5. Each jurisdiction should reevaluate and refine to the extent necessary the definition of the "practice of law".

6. Jurisdictions should retain and enforce laws that generally bar the practice of law by entities other than law firms.

7. The sharing of legal fees with nonlawyers and the ownership and control of the practice of law by nonlawyers are inconsistent with the core values of the legal profession.

8. The law governing lawyers, that prohibits lawyers from sharing legal fees with nonlawyers and from directly or indirectly transferring to nonlawyers ownership or control over entities practicing law, should not be revised.

FURTHER RESOLVED that the Standing Committee on Ethics and Professional Responsibility of the American Bar Association shall, in consultation with state, local and territorial bar associations and interested ABA sections, divisions, and committees undertake a review of the Model Rules of Professional Conduct ("MRPC") and shall recommend to the House of Delegates such amendments to the MRPC as are necessary to assure that there are safeguards in the MRPC relating to strategic alliances and other contractual relationships with nonlegal professional service providers consistent with the statement of principles in this Recommendation.

FURTHER RESOLVED that the American Bar Association recommends that in jurisdictions that permit lawyers and law firms to own and operate nonlegal businesses, no nonlawyer or nonlegal entity involved in the provision of such services should own or control the practice of law by a 
lawyer or law firm or otherwise be permitted to direct or regulate the professional judgment of the lawyer or law firm in rendering legal services to any person.

FURTHER RESOLVED that the Commission on Multidisciplinary Practice be discharged with the Association's gratitude for the Commission's hard work and with commendation for its substantial contributions to the profession.

[21] Available from the ABA MDP Commission Homepage.

[22] Laurel S. Terry, Appendix B-1 through B-7, 12 March 1999 Testimony (Summarizing the testimony of all previous witnesses) available at the ABA MDP Commission web page devoted to the March 1999 hearings, http://www.abanet.org/cpr/multicomsched399.html. (These charts and the Issue Checklist were the basis for the Commission's comment in n. 3 of Appendix D to its June 1999 Report and Recommendation that it "would like to acknowledge the comprehensive and exceedingly helpful research that was provided by Professor Laurel S. Terry".) This author was the last individual to testify before the ABA MDP Commission before it issued its first report. As part of my testimony, I submitted a 40-item Issue Checklist that set forth the issues that I believed the ABA MDP Commission should consider before changing the Model Rules to permit MDPs. I also submitted seven charts that organised, according to these 40 issues, the testimony of all individuals who previously had appeared before the ABA MDP Commission. All of these charts and the Issue Checklist appear on the Commission's website as links from the testimony of Laurel S. Terry during the 12 March 1999 hearings. See Laurel S. Terry, MDP Issue Checklist, Appendix A to 12 March 1999 Testimony, available at http://www.abanet.org/cpr/terrryappendixa.html and also reprinted in Terry, MDP primer, op. cit. at 950 and in Gary A. Munneke \& Ann L. MacNaughton (Eds), Multidisciplinary Practice: Staying Competitive and Adapting to Change (ABA Law Practice Management Section, 2001).

[23] Available as a link from the ABA MDP Commission Homepage.

[24] American Bar Association, Commission on Multidisciplinary Practice, Updated State Activity Chart, available at http://www.abanet.org/cpr/mdp_state_summ.html and Updated Narrative, available at http://www.abanet.org/cpr/mdp_state_action.html.

[25] Links to Web pages containing State Bar Rules and Regulatory Agencies available at http:// www.abanet.org/cpr/links.html.

[26] Law Society of England and Wales, Multi-disciplinary Practices-Why? Why Not? Consultation paper issued by the Law Society in October 1998, available at http://www.lawsociety.org.uk/dcs/ third_tier.asp?section $\_$id $=893$ and as a link from the ABA MDP Commission Homepage.

[27] State Bar of Texas Task Force on MDP Preliminary Report on the ABA Commission's Multidisciplinary Practice Proposal, October 1999, available at http://www.texasbar.com/attyinfo/aba/ mdprpt.pdf and as a link from the ABA MDP Commission Homepage.

[28] Lawrence J. Fox, Old wine in old bottles: preserving professional independence (1999) 72 Temple Law Review 97 1; Lawrence J. Fox, Accountants, the hawks of the professional world: they foul our nest and theirs too, plus other ruminations on the issue of MDPs (2000) 84 Minnesota Law Review 1097.

[29] Fox, 1999, op. cit.; Report of Special Committee on Multi-Disciplinary Practice and the Legal Profession (New York State Bar Association) available at http://www.nysba.org/multidiscrpt.html (influential 400 page report recommending no change in Rule 5.4, which forbids MDPs).

[30] Pennsylvania Bar Association MDP Task Force; Philadelphia Bar Association Task Force Report available as links from the ABA MDP Commission Homepage; Terry, MDP Primer, op. cit.

[31] Richard W. Painter, Lawyers' rules, auditors' rules and the psychology of concealment (2000) 84 Minnesota Law Review 1399.

[32] Fox, 1999, op. cit.

[33] The Phyllis W. Beck Chair in Law Symposium: New Roles, No Rules? Redefining Lawyers' Work (Winter 1999) 7(4) Temple Law Review [includes articles or essays about MDPs by Professors Galler, Luban, Kairys, Myers, Pearce, Terry, and lawyers Fox, Jones and Reich, Vernick and Horn].

[34] Symposium on Multidisciplinary Practice (June 2000) 84 Minnesota Law Review 1083 [includes articles by Professors Adams, Hazard, Green, Kostant, Matheson, Needham, Painter, Powell, 
Schneyer, Stein, Terry and Wolfram and lawyers Fox, Jones, and Noteboom and former dean and lawyer Manning].

[35] Business Law Symposium: Multidisciplinary Practice (Spring 2001) 36 Wake Forest Law Review 1 [includes articles by Professors Cone, Grossfeld, Kostant, Levinson, Painter, Powell, and lawyer Traynor].

[36] Mary Daly, Choosing wise men wisely: the risks and rewards of purchasing legal services from lawyers in a multidisciplinary partnership (2000) 8 Georgetown fournal of Legal Ethics 217.

[37] Terry, MDP primer, op. cit.

[38] Stephen J. McGarry, Multi-disciplinary partnerships: lawyers, consultants and clients (2001, forthcoming) American Law Media; Laurel S. Terry, German MDPs: lessons to learn (2000) 84 Minnesota Law Review 1547; Laurel S. Terry \& Clasina B. Houtman Mahoney, What if ... ? The consequences of court invalidation of lawyer-accountant multidisciplinary partnership bans, in: Private Investments Abroad-Problems $\mathcal{E}$ Solutions in International Business in 1998 (Matthew Bender, 1999), Ch. 7 (this article was cited favorably in note 7 of the ABA MDP Commission Background Report, which said: "For a thorough and comprehensive analysis of the ethical issues raised by MDPs in the United States, see Laurel S. Terry, What If?...). 